\title{
РЕЗУЛЬТАТИ ДИСЕРТАЦІЙНИХ
}

\section{ТА НАУКОВО - ДОСЛІДНИХ РОБІТ}

УДК: 616.125.6-007.253-005-071-73.439.19-053.32

\section{А.Д. Бойченко, М.О. Гончарь, І.Ю. Кондратова,А.В. Сенаторова}

КРИТЕРІЇ ДІАГНОСТИКИ

ГЕМОДИНАМІЧНО ЗНАЧУЩОЇ

ВІДКРИТОЇ АРТЕРІАЛЬНОЇ ПРОТОКИ

У НЕДОНОШЕНИХ НОВОНАРОДЖЕНИХ

Харківський національний медичний університет, Регіональний перинатальний центр, (м.Харків, Україна)

Ключові слова: недоношені новонароджені, гемодинамічно значущяа відкрита артеріальна протока, неонатальний період.
Резюме. У статті представлені результати клінічного та допплерехокардіографічного спостереження за недоношеними новонародженими, що реалізовано в алгоритмі діагностики гемодинамічно значущої відкритої артеріальної протоки.

\section{Вступ}

На теперішній час суттєвою проблемою залишаються питання виходжування недоношених дітей, особливо 3 низькою та екстремально низькою масою тіла при народженні. Відкрита артеріальна протока у недоношених може мати важкі клінічні наслідки, особливо в період одужання від респіраторного дистрес-синдрому (РДС). На стан новонародженої дитини впливає гемодинамічний статус, який суттєво залежить від функціонуючої відкритої артеріальної протоки $[1,2]$.

Гемодинамічно значуща відкрита артеріальна протока (ГЗВАП) - особливий патологічний стан, що може бути у глибоко недоношених новонароджених. У новонароджених з масою тіла менше 2000 г ГЗВАП виявляється приблизно у 40\%, а у дітей, гестаційний вік яких менше 30 тижнів - приблизно від 60 до $80 \%[1,3]$. Гемодинамічна значущість відкритої артеріальної протоки обумовлює важку дихальну недостатність, киснезалежність, що вимагає проведення тривалої штучної вентиляції легенів. Остання, в свою чергу, може бути причиною розвитку інфекційних ускладнень і навіть бронхолегеневої дисплазії $[1,4,5]$. ГЗВАП $є$ причиною синдрому «обкрадання» церебрального та мезентеріального кровотоків у новонароджених, саме тому його існування пов'язують 3 високим ризиком розвитку внутришньошлуночкових крововиливів та некротичного ентероколіту $[1,6]$.

У новонароджених гестаційного віку менше 28 тижнів і з вагою менше 1000 г потреба в закритті гемодинамічно значущої ВАП становить 55-70\% [1]. При природному перебігу ГЗВАП у недоношеної дитини ймовірність його самостійного закриття становить у $34,7 \%[1,4]$, а в разі його персистування необхідно хірургічне закриття у віці до 1 року життя.

Таким чином, пошук маркерних ознак гемодинамічної значущості відкритої артеріальної протоки набуває особливої уваги в умовах необхідності підвищення виживаності глибоко недоношених новонароджених та профілактики розвитку ранньої інвалідизації.
Метою дослідження стало удосконалення ранньої діагностики гемодинамічно значущої відкритої артеріальної протоки у недоношених новонароджених у неонатальному періоді шляхом визначення об'єктивних клінічних та допплерехокардіографічних критеріїв.

\section{Матеріали та методи дослідження}

Обстежено 84 новонароджених (хлопчики - 51,2\%, дівчатка - 49,8\%) з гестаційним віком 24-35 тижнів. Допплерехокардіографічне дослідження (ДЕХОКГ) проводилося на апараті «MyLab25Gold» фірми «Еsaote» (Італія) за розширеним протоколом (з визначенням показників центральної гемодинаміки та діастолічної функції шлуночків), також вивчався церебральний, нирковий та мезентеріальний кровотоки з визначенням IR y магістральних судинах. ДЕХОКГ проводилося всім новонародженим відразу після народження або у першу добу життя, через 48 та 72 години, на 5-7 добу життя та через дві доби.

3 метою визначення морфометричних даних й показників центральної гемодинаміки новонароджені були розподілені на групи залежно від маси тіла. До першої групи $(\mathrm{n}=21)$ увійшли діти з екстремально низькою масою тіла (маса при народженні $779,5 \pm 63,4$ г, довжина тіла - 33,3 $\pm 0,4$ см) зі строком гестації 24-29 тижнів. Друга група $(\mathrm{n}=25)$ - новонароджені дуже низької маси тіла $(1297,1 \pm 112,6$ г, довжина - 38,4 $\pm 1,32$ см) 30-34 тижнів гестації, третю групу $(\mathrm{n}=38)$ склали новонароджені з низькою масою тіла $(1859,1 \pm 118,1$ г, довжина тіла - 42,8土0,9 см) 31-35 тижнів гестації.

Отримані дані оброблені за допомогою методу варіаційної статистики, а також непараметричного критерію Манна-Уїтні для рівняння двох незалежних ненормально розподілених вибірок.

\section{Результати дослідження}

Аналіз перебігу вагітності показав, що у 82,1\% $(\mathrm{p} \leq 0,05)$ матерів мало місце іiі ускладнений перебіг у вигляді загрози передчасних пологів у 64,3\% $(\mathrm{p} \leq 0,05)$ обстежених, прееклампсія і гестоз вагіт- 
ності визначався у 38,1\%, відшарування плаценти у $30,9 \%$ жінок. Анемія вагітних зареєстрована у 21,4\% породіль. 32,1\% дітей народжені шляхом кесаревого розтину в зв'язку 3 наростанням тяжкості прееклампсії й появи ознак порушення життєдіяльності плоду, а також наявності важкої екстрагенітальної патології в жінок. 30,9\% дітей народжені від другої та наступної вагітностей, від багатоплідної вагітності - 8,3\% немовлят. За анамнестичним та інструментальними даними антенатальний дистрес плоду встановлений у 39,3\% обстежених, що стало наслідком несприятливих умов внутрішньоутробного розвитку при обтяженому перебігу вагітності на тлі супутньої соматичної патології у $57,1 \%(\mathrm{p} \leq 0,05)$ матерів. Діагноз асфіксія встановлений у 30,9\% недоношених. Терапію сурфактантом отримали 5 дітей першої групи з приводу тяжкого РДС.

У $9(10,7 \%)(\mathrm{p}<0,05)$ першої групи встановлено ГЗВАП у відповідності до критеріїв у розробленому алгоритмі (рис. 1) [7]. До ранніх ускладнень (у перші 7 діб після народження), що свідчать про наявність ГЗВАП було віднесено: збільшення тяжкості РДС - у 4 (44,4\%) пацієнтів, у 3 (33,3\%) недоношених у перші дві доби після народження діагностовано внутришньошлуночковий крововилив I-II ст., у 2 $(22,2 \%)$ зареєстроване тривале геморагічне відділення 3 трахео-бранхіального дерева, у 5 (55,5\%) - погане засвоєння ентерального харчування та підвищення ризику розвитку НЕК, у однієї дитини - зниження діурезу, у 3 (33,3\%) обстежених - нестійкі показники насичення крові киснем. Під час аускультації серця вислуховувся систолічний шум в II-III міжребер'ї зліва від грудини - у 4 (44,4\%) недоношених, інтенсивність якого залежала від динаміки РДС та середнього тиску у легеневій артерії.

При ультразвуковому дослідженні серця встановлені морфологічні зміни камер серця та порушення внутришньосерцевої гемодинаміки, що представлено у таблиці 1.

Таблиця 1

\section{Ехокардіографічні показники у недоношених новонароджених 3 гемодинамічно значущою відкритою артеріальною протокою}

\begin{tabular}{|l|c|}
\hline \multicolumn{1}{|c|}{ Ознаки } & Кількість обстежених $(\mathrm{n}=9)$ \\
\hline $\begin{array}{l}\text { Дилатація порожнини лівого шлуночказ помірною гіпертрофією } \\
\text { стінки та міжшлуночкової перетинки у апікальній частині }\end{array}$ & $77,8 \pm 17,6 \%(\mathrm{p} 1 \backslash 2 ; 1 / 3<0,05)$ \\
\hline Дилатація порожнини правого шлуночка & $70,0 \pm 16,2 \%(\mathrm{p} 1 \backslash 2 ; 1 / 3<0,05)$ \\
\hline Дилатація порожнини лівого передсердя & $100 \%(\mathrm{p} 1 \backslash 2 ; 1 / 3<0,05)$ \\
\hline РегургітаціяІ-ІІ ст. на трикуспидальном та пульмональном клапанах & $65,0 \pm 16,8 \%(\mathrm{p} 1 \backslash 2 ; 1 / 3<0,05)$ \\
\hline Підвищення середнього тиску в ЛА & $77,8 \pm 17,6 \%(\mathrm{p} 1 \backslash 2 ; 1 / 3<0,05)$ \\
\hline Підвищення скорочувальної здатності міокарда & $10,0 \pm 10,0 \%$ \\
\hline Зниження скорочувальної здатності міокарда & $22,2 \pm 14,6 \%$ \\
\hline
\end{tabular}

Примітка: p1।2; 1/3<0,05 - вірогідність відзнак між групами.

У 100\% обстежених встановлено функціонування фетальних комунікацій: діаметр відкритого овального отвору у дітей першої групи складав $2,7 \pm 0,5$ мм,

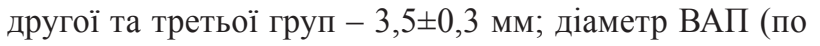
потоку у стовбурі ЛА) у першій групі - 2,5 $\pm 0,8$ мм, у

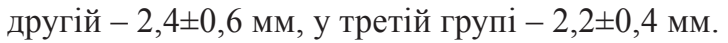

У всіх новонароджених, яким встановлено діагноз гемодинамічно значущої відкритої артеріальної протоки зареєстровано порушення діастолічної функції лівого та правого шлуночків серця за типом уповільненої релаксації. Гіперкінетичний варіант центральної гемодинаміки виявлено у 44,4\% новонароджених дітей, еукінетичний - у 33,3\% обстежених та гіпокінетичний - у 22,2\% немовлят, які знаходилися у тяжкому стані з клінічними ознаками ускладнень ГЗВАП.

Наявність ВАП (iї діаметр) та тривалість функціонування має відбиток на типі режиму гемодинаміки, про що свідчить зворотній кореляційний зв'язок iз систолічним індексом $(\mathrm{r}=-0,45, \mathrm{p}<0,05)$ та $(\mathrm{r}=-0,48$, $\mathrm{p}<0,05$ відповідно).

Хірургічне лікування ГЗВАП було проведено шістьом новонародженим з 7 по 18 сутки життя, у трьох пацієнтів сталася спонтанна облітерація протоки.

Резюмуючи все вище зауважеже можна відзна- чити основну тенденцію в терапії ГЗВАП - закриття протоки якомога раніше i, за можливості, до появи ускладнень. Загальноприйнята думка щодо оптимального терміну закриття ГЗВАП на другому тижні життя у недоношених новонароджених: на нашу думку, це питання повинно вирішуватися індивідуально на користь більш раннього іiі закриття. Рішення про необхідність та строк хірургічного лікування (перев'язка) ГЗВАП повинно прийматися індивідуально на основі клінічного та ультразвукового обстеження серця новонародженого.

\section{Висновки}

Критерії клінічної та інструментальної діагностики гемодинамічно значущої відкритої артеріальної протоки є необхідним впровадити у план обстеження недоношених новонароджених 3 вагою менше 1500 грамів.

Основними клінічними проявами гемодинамічно значущої відкритої артеріальної протоки слід вважати: залежність від кисню, збільшення тяжкості респіраторного дистрес-синдрому, погане засвоєння ентерального харчування, наявність неврологічної симптоматики на тлі внутрішньошлуночкових крововиливів. 
Частота ГЗФАП обернено пропорційна строку гестації, частіше зустрічається у недоношених 3 екстремально низькою масою тіла. Морфологічні зміни камер серця та клінічне погіршення стану новонародженого свідчить про необхідність вирішення питання хірургічної корекції ГЗВАП.

Розроблений алгоритм діагностики та спосте-

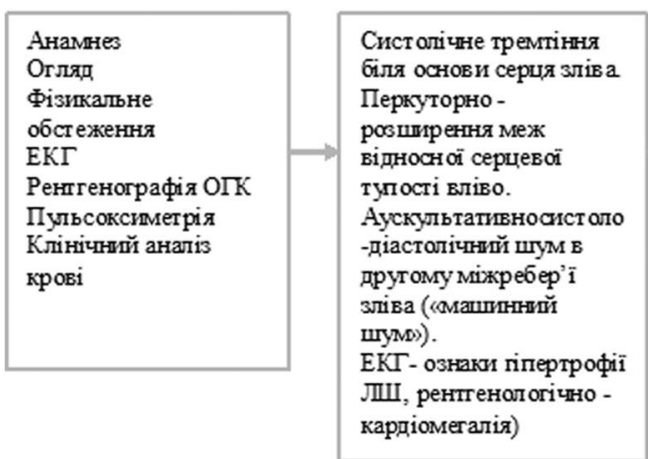

реження новонароджених з ВАП може бути використаний у практичній охороні здоров'я.

\section{Перспективи подальших досліджень}

Вважаємо доцільним проводити подальші дослідження 3 метою вдосконалення показань до раннього закриття гемодинамічно значущої відкритої артеріальної протоки.

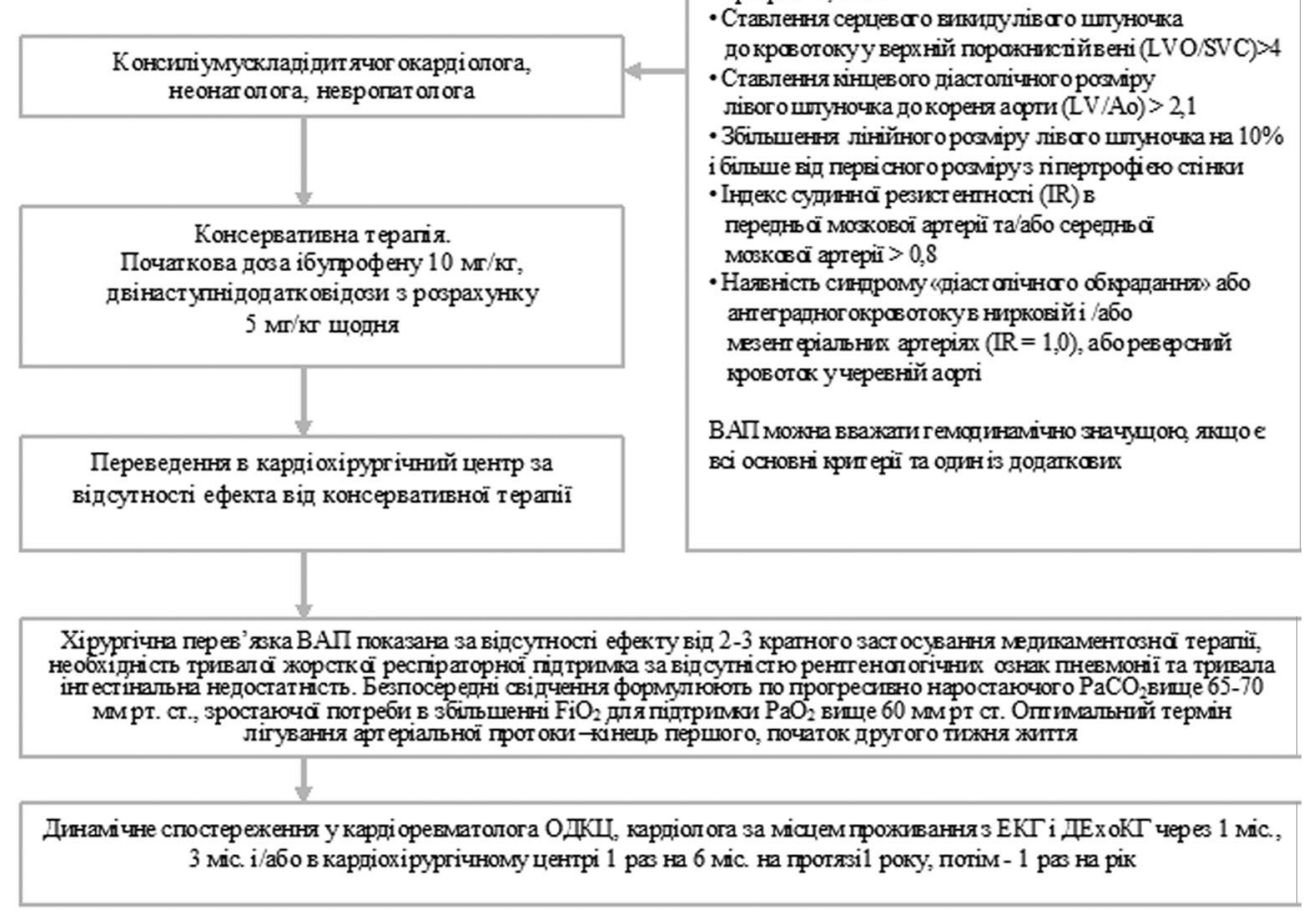

\author{
Кансульташіядитяча окардіоревметата, ДЕХОКТ \\ Oсновнікритерії емдринамічної \\ - Залежність від киснго

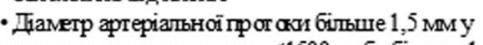 \\ нов народжених 3 вагсо <1500 г або більше $1,4 \mathrm{Mm} / \mathrm{kr}$ \\ унсонароджених 3 вагою $>1500 \mathrm{r}$ \\ - Наявність ліво-правсто шунтуванни крові по \\ протоку $Q p / Q s>1,5$ \\ - Наявність ретратраднато кров от ау в постдуктальнай \\ асрті, що становить $>50 \%$ антеградна окравотоку \\ - Кардіоторакальнийіндекс $>60 \%$ \\ Додаткові критеріі геморинаміноізанишості ВАП: \\ - Співвідношенни розмірулівого передсердя до \\ кореня аорти (LA/Ao)>1,4 \\ - Дастолічна швидкість юров ог ауу в легеневій \\ aprepii $>0,2 \mathrm{~m} / \mathrm{s}$ \\ Ставлення серцев с о викидуліва о ппуночка \\ докров отокуу верхній порокнистйьені (LVO/SVC)>4 \\ Ставлення кіншев ого діастолічног о розміру \\ лівого штуночка до корени асрти (LV/Ao) $>2$,

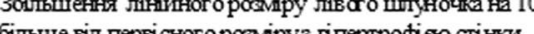 \\ Iндекс судинао резист ентност (IR) в

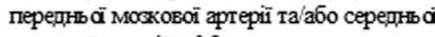 \\ MOSKGE ä aprepiï >0,8

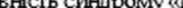 \\ антеграрног окровотокув нирковій $i$ /аб. \\ мезент еріальних артеріях (IR $=1,0)$, абореверсний
}

ВАП можна вЕажати геморинамічно Зачущою, якщо е всі основні крит еріі та один із додатксик

Рис.1. Алгоритм діагностики та ведення новонароджених з ВАП

\section{Література}

1. Shannon E.G. Hamrick Ductus Arteriosus of the Preterm Infant // Shannon E.G. Hamrick, Georg Hansmann // Pediatrics.- 2010. - Vol. 125, № 5. - P. 1020-1030.

2. Протокол ведения недоношенных детей с гемодинамически значимым функционирующим артериальным протоком; под. ред. Н.Н. Володина, Е.Н. Байбариной. - М., 2010. - 29 с.

3. Ефремов С.О. Открытый артериальный проток у недоношенных детей: тактика ведения и показания к хирургическому лечению: автореф. дисс. на соискание уч. степени канд. мед.наук / С.О. Ефремов. - М., 2010. - 25 с.

4. Arun Sasi Patent Ductus Arteriosus in Preterm Infants / Arun Sasi, Ashok Deorari. - Indian. Pediatrics. - 2011.- V. 48. - P. 301-308.

5. Joseph W. Kaempf Permissive tolerance of the patent ductus arteriosus may increase the risk of Chronic Lung Disease / Joseph W. Kaempf, Robert Huston, Ying Xing Wu [et al.] // Research and Reportsin Neonatology.-2013. - Vol.3.- P. 5-10.

6. Современные представления об открытом артериальном протоке у новорожденных / Д.С.Крючко, А.Г. Антонов, А.А. Ленюшкина [и др.]. - Педиатрия. - 2011. - Т.90, № 1.- С. 130-136.

7. Діагностика та моніторинг вроджених вад серця у новонароджених: навч. посіб. / [Волосовець О.П., Сенаторова Г.С., Гончарь М.О., Бойченко А.Д.].- Харків, 2013.- 108 с. 


\section{КРИТЕРИИ ДИАГНОСТИКИ \\ ГЕМОДИНАМИЧЕСКИ ЗНАЧИМОГО ОТКРЫТОГО АРТЕРИАЛЬНОГО ПРОТОКА У НЕДОНОШЕННЫХ НОВОРОЖДЕННЫХ}

\author{
А.Д.Бойченко, М.А.Гончарь, \\ И.Ю.Кондратова, А.В.Сенаторова \\ Харьковский национальный \\ медицинский университет, \\ Региональный перинатальный центр \\ (г. Харьков, Украина)
}

Резюме. В статье представлены результаты клинического и допплерэхокардиографического наблюдения за недоношенными новорожденными, что реализовано в алгоритме диагностики гемодинамически значимого открытого артериального протока.

Ключевые слова: недоношенные новорожденные, гемодинамически значимый открытый артериальный проток, неонатальный период.

\section{CRITERIA OF THE DIAGNOSIS}

OF HEMODYNAMICALLY SIGNIFICANT

PATENT DUCTUS ARTERIOSUS

IN PRETERM INFANTS

A.D.Boychenko, M.A.Gonchar,

I.Yu.Kondratova, A.V.Senatorova

\section{Kharkiv National}

Medical University, Regional Perinatal Center

(Kharkiv, Ukraine)

Summary. The article presents the results of a clinical and Doppler ultrasound observation of preterm infants, which is implemented in the diagnostic algorithm of hemodynamically significant patent ductus arteriosus.

Keywords: preterm infants, hemodynamically significant patent ductus arteriosus, neonatal period. 